\title{
Kekasaran Permukaan Resin Komposit Nanofilled dan Nanohybrid Setelah Paparan Asap Rokok Kretek
}

\author{
(Surface Roughness of Nanofilled and Nanohybrid Composite Resins Exposed to \\ Kretek Cigarette Smoke)
}

\author{
Johanna Chandra ${ }^{1}$, Laksmiari Setyowati ${ }^{2}$ and Setyabudi ${ }^{2}$ \\ ${ }^{1}$ Mahasiswa Pendidikan Dokter Gigi \\ ${ }^{2}$ Staf Pengajar Departemen Konservasi Gigi Kedokteran Gigi \\ Fakultas Kedokteran Gigi Universitas Airlangga \\ Surabaya-Indonesia
}

\begin{abstract}
Background: Cigarette smoking is a public health problem that may influence physical properties of dental composites. Surface roughness is one of the physical properties of restorative materials that can influence their success. The use of nanofilled and nanohybrid composites in dentistry has substantially increased over the past few years. Purpose: The purpose of this study was to evaluate the surface roughness of nanofilled and nanohybrid composite resins exposed to kretek cigarette smoke. Methods: Twelve cylindrical specimens were prepared of each material and divided into two groups $(n=6)$. For the control groups, the specimens were immersed in distilled water for 24 hours at $37^{\circ} \mathrm{C}$ and the water was renewed daily. For the experimental groups, the specimens were exposed daily to kretek cigarette smoke, then washed and stored in distilled water at $37^{\circ} \mathrm{C}$. After 21 days, specimens were measured using a Surface Roughness Tester and the data was statistically analyzed. Result: Independent-T Test revealed that there were statistically significant differences in the surface roughness between control and experimental groups both nanofilled and nanohybrid, and between experimental groups nanofilled and nanohybrid. Conclusion: The exposure to kretek cigarette smoke can significantly increase the surface roughness of nanohybrid composites more than nanofilled composites.
\end{abstract}

Keywords: Composite resin; Nanofilled; Nanohybrid; Surface roughness; Kretek cigarette smoke.

\begin{abstract}
ABSTRAK
Latar Belakang: Merokok merupakan masalah kesehatan masyarakat yang dapat mempengaruhi sifat fisik resin komposit. Kekasaran permukaan merupakan salah satu sifat fisik bahan restorasi yang dapat mempengaruhi keberhasilan restorasi. Penggunaan komposit nanofilled dan nanohybrid dalam kedokteran gigi meningkat dalam beberapa tahun terakhir. Tujuan: Tujuan dari penelitian ini adalah untuk mengetahui kekasaran permukaan resin komposit nanofilled dan nanohybrid setelah paparan asap rokok kretek. Metode: Sampel berbentuk silindris dibuat sejumlah dua belas buah untuk masing-masing komposit dan dibagi menjadi dua bagian $(\mathrm{n}=6)$. Pada kelompok kontrol, sampel direndam dalam akuades selama 24 jam dengan suhu $37^{\circ} \mathrm{C}$ dan akuades diganti baru setiap hari. Pada kelompok perlakuan, sampel dipapar asap rokok kretek setiap hari, kemudian dibilas dan direndam dalam akuades dengan suhu $37^{\circ} \mathrm{C}$. Setelah 21 hari, kekasaran permukaan sampel diukur menggunakan Surface Roughness Tester dan data diuji secara statistik. Hasil: Uji Independent-T Test menyatakan bahwa terdapat perbedaan signifikan kekasaran permukaan antara kelompok kontrol dan perlakuan pada komposit nanofilled dan nanohybrid, dan antara kelompok perlakuan nanofilled dan perlakuan nanohybrid. Simpulan: Asap rokok kretek dapat meningkatkan kekasaran permukaan pada resin komposit nanohybrid dibandingkan dengan resin komposit nanofilled.
\end{abstract}

Kata kunci: Resin komposit; Nanofilled; Nanohybrid; Kekasaran permukaan; Asap rokok kretek.

Korespondensi (correspondence): 1. Johanna Chandra, Mahasiswa Pendidikan Dokter Gigi, Fakultas Kedokteran Gigi Universitas Airlangga. J1. Prof. Moestopo 47, Surabaya. E-mail: jo.chan_95@ymail.com. 


\section{PENDAHULUAN}

Resin komposit merupakan salah satu bahan restorasi yang banyak digunakan dalam kedokteran gigi. Resin komposit nano merupakan perkembangan komposit terbaru, dengan ukuran filler yang semakin kecil (1-100 nanometer) dan konsentrasi filler yang meningkat, sehingga sifat fisik, mekanis, dan estetiknya meningkat. ${ }^{1}$ Terdapat dua tipe komposit yang mengandung partikel nano, yaitu komposit nanofilled (seluruh filler berukuran nano) dan komposit nanohybrid (sebagian filler berukuran nano dan sebagian berukuran mikro). ${ }^{2}$

Sifat bahan restorasi resin komposit dapat dipengaruhi oleh beberapa faktor, antara lain komposisi matriks, filler, coupling agent, teknik bonding, dll. ${ }^{3}$ Perilaku gaya hidup individu, contohnya merokok, juga dapat mempengaruhi sifat bahan restorasi. ${ }^{4}$

Merokok merupakan masalah kesehatan yang sangat umum dan meluas di masyarakat. Menurut data WHO, Indonesia merupakan negara ketiga dengan jumlah perokok terbesar di dunia setelah Cina dan India. Kecenderungan merokok terus meningkat dari tahun ke tahun. Berdasarkan Riskesdas 2013, jumlah perokok aktif yang merokok setiap hari di Indonesia yaitu 24,3\% dan rata-rata jumlah rokok yang dihisap yaitu 12,3 batang per hari. ${ }^{5}$

Banyak bahan toksik terkandung di dalam tembakau atau diproduksi selama pembakaran yang berpotensi menyebabkan penyakit. $^{6}$ Merokok dapat meningkatkan resiko karies gigi, ${ }^{3}$ sehingga diperlukan restorasi gigi. Bahan restorasi yang banyak digunakan yaitu resin komposit. Pada penelitian yang dilakukan oleh Mathias et al. (2014), didapatkan peningkatan penyerapan air ketika komposit dipapar asap rokok. ${ }^{3}$ Meskipun efek potensial pembakaran rokok dalam rongga mulut masih belum jelas, temperatur yang tinggi $\left(55^{\circ} \mathrm{C}\right)$ dapat meningkatkan kinetik difusi air, penyerapan air, dan kelarutan resin. ${ }^{4}$

Rokok kretek merupakan produk tembakau khas Indonesia yang banyak disukai dan meliputi hampir 90\% pasaran rokok di Indonesia. ${ }^{7}$ Berdasarkan Top Brand Award Index pada tahun 2012-2014 rokok kretek non filter yang paling disukai adalah merek Dji Sam Soe. Berbeda dengan rokok putih, rokok kretek menggunakan tembakau yang berat berupa tembakau rajangan dan campuran cengkeh. ${ }^{8}$ Pembakaran rokok kretek melepaskan uap eugenol dengan konsentrasi tinggi yang berasal dari cengkeh, yaitu 28.700-30.200 $\mu \mathrm{g}$ setiap 1 batang rokok (merek Dji Sam Soe). ${ }^{7}$

Proses penyerapan air dan eugenol dapat berperan sebagai plasticizer terhadap matriks komposit sehingga menyebabkan terjadinya pembengkakan yang berpengaruh pada dimensi bahan restorasi. ${ }^{9}$ Penyerapan air dapat dipengaruhi oleh konsentrasi filler, tingkat polimerisasi, tipe dan jumlah monomer. Penyerapan air dapat mengakibatkan terjadinya pelepasan monomer yang tidak bereaksi dan terjadi proses hidrolisis sehingga ikatan kimia antara filler dengan matriks resin terputus. Selain itu, degradasi polimer juga disebabkan oleh perubahan suhu mendadak yang menyebabkan kerusakan pada silane coating sehingga ikatan antara filler dengan matriks resin terputus. Degradasi matriks dan terlepasnya partikel filler pada permukaan luar komposit menyebabkan peningkatan kekasaran permukaan. ${ }^{10,11}$

Peningkatan kekasaran permukaan bahan restorasi dapat memicu pembentukan plak dan biofilm sehingga meningkatkan resiko karies dan inflamasi periodontal. Kekasaran permukaan juga dapat mempengaruhi estetik, yaitu menurunkan kecerahan restorasi dan meningkatkan kerentanan terhadap perubahan warna; serta dapat memperpendek usia restorasi. ${ }^{12,13}$

Tujuan dari penelitian ini adalah untuk mengetahui kekasaran permukaan resin komposit nanohybrid dan nanofilled setelah paparan asap rokok kretek. Hipotesis dari penelitian ini yaitu asap rokok kretek dapat meningkatkan kekasaran permukaan pada resin komposit nanohybrid dibandingkan pada resin komposit nanofilled.

\section{BAHAN DAN METODE}

Penelitian ini merupakan eksperimental laboratoris dengan rancangan post test only control group design. Sampel penelitian ini yaitu resin komposit nanofilled (Filtek Z350 XT) dan nanohybrid (Filtek Z250 XT), berbentuk silindris dengan diameter $5 \mathrm{~mm}$ dan ketebalan $2 \mathrm{~mm}$ sebanyak 24 buah. Sampel dibagi menjadi 4 kelompok $(\mathrm{n}=6)$, yaitu kelompok kontrol nanofilled, kontrol nanohybrid, perlakuan nanofilled, dan perlakuan nanohybrid.

Pembuatan sampel diawali dengan pembuatan cetakan dari syringe insulin dengan diameter $5 \mathrm{~mm}$ dan tebal $2 \mathrm{~mm}$, kemudian diberi alas celluloid strip dan diletakkan di atas plat 
kaca. Resin komposit dimasukkan ke dalam cetakan sampel hingga penuh, lalu ditutup dengan celluloid strip dan plat kaca di atasnya, kemudian diberi beban anak timbangan $1 \mathrm{~kg}$ selama 30 detik supaya permukaan sampel sama rata dan padat. ${ }^{13}$ Anak timbangan dan plat kaca diangkat, komposit disinari dengan light curing unit selama 20 detik dengan intensitas $600-700 \mathrm{~mW} / \mathrm{cm}^{2}$ (sesuai aturan pabrik: $400-1000 \mathrm{~mW} / \mathrm{cm}^{2}$ ), dan jarak antara tip unit dengan komposit 0,5-1 mm. ${ }^{2}$ Resin komposit yang telah mengeras dikeluarkan dari cetakan.

Komposit kelompok kontrol direndam dalam akuades dan diinkubasi dengan suhu $37^{\circ} \mathrm{C}$ selama 21 hari. Sedangkan, kelompok perlakuan diberi paparan asap rokok kretek sebanyak 12 batang menggunakan smoking machine, dengan suhu paparan di dalam tabung $55^{\circ} \mathrm{C}$ (menggunakan water bath) (Gambar 1). ${ }^{4}$ Masingmasing batang rokok dihisap ke dalam tabung selama 10 menit. ${ }^{14}$ Kemudian seluruh asap rokok dikeluarkan dari tabung. Setelah paparan 12 batang rokok selesai, sampel direndam dalam akuades dan diinkubasi dengan suhu $37^{\circ} \mathrm{C}$ selama \pm 21 jam. Setelah itu, komposit kelompok perlakuan diambil dari akuades dan dikeringkan menggunakan absorb paper. Kemudian langkah di atas diulang kembali selama 21 hari. Akuades diganti baru setiap hari untuk semua kelompok.

Setelah 21 hari, sampel kelompok kontrol dan perlakuan diambil dari akuades dan dikeringkan menggunakan absorb paper. Komposit kelompok perlakuan direndam dalam aseton sambil digoyangkan selama \pm 1 menit $^{15}$ untuk melarutkan lapisan tar rokok yang menempel di permukaan sampel. ${ }^{16}$ Kekasaran permukaan sampel diukur menggunakan alat Surface Roughness Tester (Mitutoyo SJ-201) dengan stylus standar pada tiga area yang berbeda (Gambar 2), kemudian dihitung rata-rata dari ketiga nilai tersebut. ${ }^{13}$

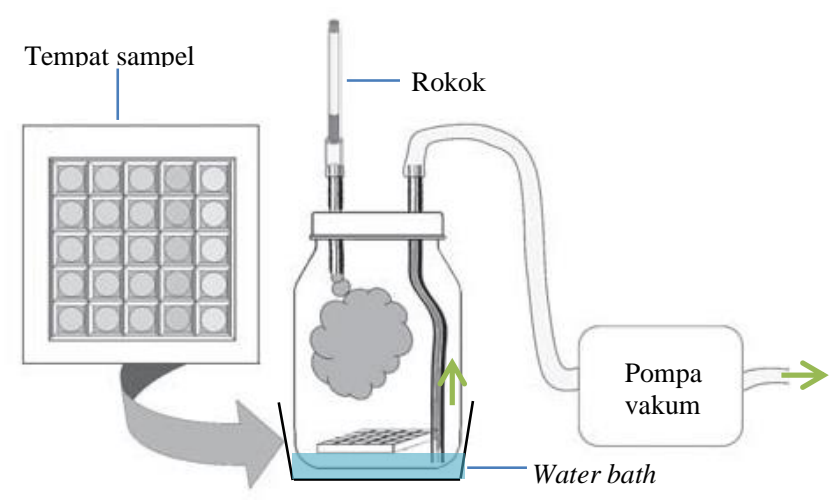

Gambar 1. Smoking machine yang digunakan untuk penelitian. ${ }^{14}$

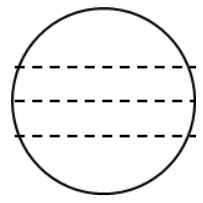

Gambar 2. Pola area pengukuran sampel. ${ }^{13}$

Hasil pengukuran kekasaran permukaan komposit dianalisis secara statistik menggunakan Independent-T Test dengan derajat kepercayaan $95 \%$.

\section{HASIL}

Pada penelitian ini terdapat 4 kelompok sampel, yaitu kelompok kontrol nanofilled, kontrol nanohybrid, perlakuan nanofilled, dan perlakuan nanohybrid. Penelitian dilakukan selama 21 hari dan kemudian setiap sampel diukur kekasaran permukaannya menggunakan alat Surface Roughness Tester (Mitutoyo SJ-201). Parameter yang digunakan yaitu kekasaran ratarata $R_{a}$, dengan satuan mikrometer $(\mu \mathrm{m})$. Nilai rata-rata dan standar deviasi kekasaran permukaan resin komposit dapat dilihat pada Tabel 1.

Tabel 1. Rata-rata dan standar deviasi nilai kekasaran permukaan resin komposit nanofilled dan nanohybrid.

\begin{tabular}{|cccc}
\hline Kelompok Sampel & $\mathbf{n}$ & $\begin{array}{c}\text { Rata-rata } \\
(\boldsymbol{\mu m})\end{array}$ & $\begin{array}{c}\text { Standar } \\
\text { Deviasi }\end{array}$ \\
\hline Kontrol nanofilled & 6 & 0,16500 & 0,024763 \\
\hline Perlakuan nanofilled & 6 & 0,27433 & 0,036779 \\
\hline Kontrol nanohybrid & 6 & 0,18000 & 0,032912 \\
\hline Perlakuan nanohybrid & 6 & 0,40183 & 0,054120 \\
\hline
\end{tabular}

Hasil uji normalitas data menggunakan One Sample Kolmogorov Smirnov Test menunjukkan bahwa data berdistribusi normal dengan nilai p>0,05. Hasil uji homogenitas data menggunakan Levene's Test menunjukkan variasi data yang homogen dengan nilai $\mathrm{p}>0,05$.

Untuk melihat adanya signifikansi perbedaan antar kelompok, dilakukan uji statistik Independent-T Test menunjukkan bahwa terdapat perbedaan signifikan kekasaran permukaan resin komposit antara kelompok kontrol nanofilled dengan perlakuan nanofilled, kontrol nanohybrid dengan perlakuan nanohybrid, dan perlakuan nanofilled dengan perlakuan nanohybrid, dengan nilai $\mathrm{p}<0,05$. Sedangkan, pada kelompok kontrol nanofilled dengan kontrol nanohybrid 
menunjukkan tidak terdapat perbedaan signifikan kekasaran permukaannya, dengan nilai $\mathrm{p}>0,05$.

Tabel 2. Hasil uji Independent T-Test kekasaran permukaan resin komposit.

\begin{tabular}{|c|c|}
\hline Kelompok yang dibandingkan & $\begin{array}{c}\text { Sig. } \\
\text { (2-tailed) }\end{array}$ \\
\hline $\begin{array}{c}\text { Kontrol Nanofilled \& Perlakuan } \\
\text { Nanofilled }\end{array}$ & $0,000^{*}$ \\
\hline $\begin{array}{c}\text { Kontrol Nanohybrid \& Perlakuan } \\
\text { Nanohybrid }\end{array}$ & $0,000 *$ \\
\hline $\begin{array}{c}\text { Kontrol Nanofilled \& Kontrol } \\
\text { Nanohybrid }\end{array}$ & $0,395 * *$ \\
\hline $\begin{array}{c}\text { Perlakuan Nanofilled \& Perlakuan } \\
\text { Nanohybrid }\end{array}$ & $0,001 *$ \\
\hline $\begin{aligned} \text { Keterangan: } & * \text { terdapat perbedaan signifi } \\
& * * \text { tidak terdapat perbedaan }\end{aligned}$ & iifikan. \\
\hline
\end{tabular}

\section{PEMBAHASAN}

Penelitian ini dilakukan untuk melihat pengaruh paparan asap rokok kretek terhadap kekasaran permukaan resin komposit nanofilled dan nanohybrid. Pada penelitian menggunakan rokok kretek karena banyak disukai dan meliputi hampir $90 \%$ pasaran rokok di Indonesia. ${ }^{7}$ Penelitian ini tidak menggunakan saliva buatan melainkan akuades, karena saliva buatan tidak terbukti secara klinis sebagai media penyimpanan yang lebih relevan. Pada penelitian tentang pengaruh media penyimpanan terhadap mikromorfologi resin komposit, didapatkan hasil yang sama antara akuades dengan saliva buatan. ${ }^{1}$ Pada penelitian ini juga dilakukan perendaman sampel kelompok perlakuan di dalam aseton untuk melarutkan lapisan tar rokok yang menempel di permukaan sampel. ${ }^{16}$ Berdasarkan penelitian yang telah dilakukan oleh Hamano et al. (2011), pemberian aseton pada permukaan komposit nano selama \pm 1 menit tidak berpengaruh terhadap kekasaran permukaan. Hal ini disebabkan karena resin komposit nano memiliki ikatan silang yang kuat sehingga kecil kemungkinan aseton dapat melarutkan permukaan komposit. ${ }^{15}$

Dari hasil penelitian, didapatkan perbedaan signifikan kekasaran permukaan resin komposit antara kelompok kontrol nanofilled dengan perlakuan nanofilled dan kontrol nanohybrid dengan perlakuan nanohybrid. Hal ini sesuai dengan teori degradasi komposit oleh karena peningkatan penyerapan air dan paparan asam. Suhu yang tinggi dari asap rokok dalam rongga mulut, yaitu sekitar $55^{\circ} \mathrm{C}$, dapat meningkatkan energi kinetik difusi air sehingga penyerapan air ke dalam resin komposit meningkat. ${ }^{4}$ Penyerapan air dapat dipengaruhi oleh konsentrasi filler. Peningkatan jumlah filler dapat menurunkan penyerapan air. ${ }^{17}$ Resin komposit yang digunakan pada penelitian ini yaitu, komposit nanofilled (Filtek Z350 XT) memiliki konsentrasi volume filler sebanyak 59,5\% dan komposit nanohybrid (Filter Z250 XT) memiliki konsentrasi volume filler sebanyak $68 \%$. Oleh karena itu, penyerapan air pada komposit nanofilled lebih banyak dibandingkan pada komposit nanohybrid.

Penyerapan air dapat menyebabkan terjadinya reaksi hidrolisis, sehingga air terurai menjadi $\mathrm{H}^{+}$dan $\mathrm{OH}^{-}$. Karena adanya unsur $\mathrm{O}$ dalam matriks resin, maka $\mathrm{OH}^{-}$dari air diserap masuk ke dalam matriks serta menyerang ikatan siloksan (Si-O-Si), yaitu ikatan yang menghubungkan matriks dan partikel filler. Hal ini mengakibatkan terputusnya ikatan siloksan sehingga terbentuk senyawa silanol $(\mathrm{Si}-\mathrm{OH})$ dan Si-O. Pada Si-O terjadi disorientasi elektron sehingga Si-O dapat bereaksi bila bertemu dengan air. Reaksi ini menghasilkan $\mathrm{Si}-\mathrm{OH}$ dan $\mathrm{OH}^{-}$. Kemudian $\mathrm{OH}^{-}$kembali akan memutuskan ikatan siloksan sehingga reaksi ini pun terjadi terus menerus selama resin komposit berada dalam perendaman air. Semakin lama reaksi ini terjadi, semakin banyak pula partikel filler yang terlepas dari permukaan resin komposit sehingga semakin besar peningkatan kekasaran yang terjadi. ${ }^{18} \mathrm{Hal}$ ini terjadi sampai komposit mencapai titik jenuhnya. ${ }^{19}$

Selain itu, pembakaran rokok kretek juga melepaskan uap eugenol dengan konsentrasi tinggi yang berasal dari cengkeh yaitu 28.700$30.200 \mu \mathrm{g}$ setiap 1 batang rokok, dengan perbandingan rata-rata konsumsi eugenol setiap hari dari makanan yaitu sekitar $70 \mu \mathrm{g} .{ }^{7}$ Eugenol termasuk dalam golongan fenol yang cenderung bersifat asam, artinya ia dapat melepaskan ion $\mathrm{H}^{+}$ dari gugus hidroksilnya. Pelepasan ion ini turut berperan pada degradasi resin komposit karena berpotensi memutuskan ikatan siloksan. ${ }^{18}$ Ion $\mathrm{H}^{+}$ bebas juga dapat bereaksi dengan karbon ikatan ganda $(C=)$ pada rantai polimer dari matriks resin sehingga rantai polimer terputus. Hal ini menyebabkan degradasi matriks resin komposit yang menyebabkan partikel filler pada permukaan 
mudah lepas. Lepasnya matriks dan partikel filler ini menyebabkan banyak celah-celah kecil pada komposit sehingga kekasaran permukaannya meningkat. ${ }^{20}$

Asap rokok memiliki banyak sekali komponen-komponen kimia lain, yaitu mencapai 4.800 macam ${ }^{21}$ yang kemungkinan juga dapat mempengaruhi kekasaran permukaan resin komposit. Namun pada penelitian ini, komponen kimia dalam asap rokok kretek yang dibahas hanya eugenol karena memiliki konsentrasi yang jauh lebih tinggi dibandingkan dengan komponenkomponen lainnya. Tidak menutup kemungkinan juga ada komponen-komponen yang bekerja secara sinergis atau berlawanan dengan eugenol. Hal ini diperlukan penelitian lebih lanjut.

Berdasarkan penelitian yang telah dilakukan oleh Eid et al. (2013), pada gambaran Scanning Electron Microscope (SEM) permukaan resin komposit kelompok kontrol didapatkan komponen matriks dan juga filler. ${ }^{12}$ Hasil penelitian kekasaran permukaan antara kelompok kontrol nanofilled dengan kontrol nanohybrid menunjukkan bahwa kontrol nanohybrid memiliki permukaan yang sedikit lebih kasar dibandingkan dengan kontrol nanofilled, namun secara statistik tidak berbeda signifikan. Hal ini sesuai dengan teori bahwa kekasaran permukaan resin komposit dapat dipengaruhi oleh ukuran dan jumlah volume filler. $^{22}$ Komposit dengan partikel filler yang berukuran lebih besar memiliki permukaan yang lebih kasar dibandingkan dengan filler berukuran kecil. ${ }^{23}$ Pada komposit nanofilled seluruh partikel filler berbentuk bulat dan berukuran nano, yaitu 1$100 \mathrm{~nm}$. Sedangkan, komposit nanohybrid memiliki partikel filler yang berbentuk ireguler dengan ukuran nano (1-100 $\mathrm{nm})$ dan mikro $(0,4-5$ $\mu \mathrm{m}){ }^{2,24}$ Oleh karena itu, komposit nanohybrid kontrol memiliki kekasaran permukaan yang sedikit lebih besar dibandingkan dengan komposit nanofilled kontrol.

Pada hasil penelitian kekasaran permukaan antara perlakuan nanofilled dengan perlakuan nanohybrid menunjukkan bahwa perlakuan nanohybrid secara signifikan lebih kasar dibandingkan dengan perlakuan nanofilled. Hal ini disebabkan karena partikel filler komposit nanohybrid $(\leq 5 \mu \mathrm{m})$ berukuran lebih besar dibandingkan dengan komposit nanofilled $(\leq 100$ $\mathrm{nm}$ ), sehingga peningkatan kekasaran permukaan pada komposit nanohybrid lebih besar dibandingkan komposit nanofilled. ${ }^{23}$ Kelompok perlakuan nanohybrid memiliki nilai kekasaran permukaan rata-rata $0,402 \mu \mathrm{m}$, sehingga ada kemungkinan filler yang terlepas yaitu filler yang berukuran kecil dan/atau sedang. Sedangkan, ikatan siloksan pada partikel filler yang berukuran besar kemungkinan hanya terputus sebagian saja sehingga filler tidak sampai terlepas. Hal ini diperlukan penelitian lebih lanjut.

Dari hasil penelitian yang telah dilakukan, maka dapat disimpulkan bahwa asap rokok kretek dapat meningkatkan kekasaran permukaan pada resin komposit nanohybrid dibandingkan dengan resin komposit nanofilled.

Diperlukan penelitian lebih lanjut mengenai komponen-komponen kimia lain yang dapat mempengaruhi kekasaran permukaan komposit. Selain itu, juga perlu dilakukan penelitian uji kekasaran permukaan resin komposit menggunakan alat Confocal Laser Scanning Microscopic (CLSM), untuk mengetahui topografi kekasaran permukaan secara detail.

\section{DAFTAR PUSTAKA}

1. Erdemir U, Yildiz E, Eren MM, Ozel S. 2013. Surface hardness evaluation of different composite resin materials: influence of sports and energy drinks immersion after a short-term period. J Appl Oral Sci; 21(2): 124-30.

2. Sakaguchi RL, Powers JM. 2012. Craig's Restorative Dental Materials. $13^{\text {th }}$ ed. Philadelphia: Elsevier Mosby, p.143;1659;179.

3. Mathias P, Santos SRB, Aguiar TR, Santos PRB, Cavalcanti AN. 2014. Cigarette smoke: effects on water sorption and solubility of restorative dental composites. Academy of General Dentistry, p.54-5.

4. Aguiar TR, Gaglianone LA, Mathias P. 2014. An Overview of the Impact of Lifestyle Behaviors on the Operative Dentistry. $J$ Interdiscipl Med Dent Sci; 2(4): 1, 4.

5. InfoDATIN. 2015. Perilaku Merokok Masyarakat Indonesia: Berdasarkan Riskesdas 2007 dan 2013. Available at: http://www.depkes.go.id/resources/download/p usdatin/infodatin/infodatin-hari-tanpatembakau-sedunia.pdf. Diakses pada 10 Mei 2016, p.2-4.

6. Bertoldo CE, Miranda D, Souza-Junior EJ, Aguiar FHB, Lima DANL, Ferreira RL, Claes I, Lovadino JR. 2011. Surface hardness and color change of dental enamel exposed to cigarette smoke. International Journal of Dental Clinics; 3(4): 1. 
7. Polzin GM, Stanfill SB, Brown CR, Ashley DL, Watson CH. 2007. Determination of eugenol, anethole, and coumarin in the mainstream cigarette smoke of Indonesian clove cigarettes. Food and Chemical Toxicology; 45: 1948-51.

8. Jonathan S. 2007. Launching for Marketer and Entrepreneur. Jakarta: PT Gramedia Pustaka Utama, p.173.

9. Darvell BW. 2009. Materials Science for Dentistry. $9^{\text {th }}$ ed. Cambridge: Woodhead Publishing, p.218.

10.Tanthanuch S, Kukiattrakoon B, Siriporananon C, Ornprasert N, Mettasitthikorn W, Likhitpreeda S, Waewsanga S. 2014. The effect of different beverages on surface hardness of nanohybrid resin composite and giomer. J Conserv Dent; 17(3): 261.

11.Soetojo A. 2013. Penggunaan Resin Komposit dalam Bidang Konservasi Gigi. Surabaya: Revka Petra Media, p.1;30;34.

12.Eid HA, Togoo RA, Saleh AA, Sumanth CR. 2013. Surface Topography of Composite Restorative Materials following Ultrasonic Scaling and its Impact on Bacterial Plaque Accumulation: an In-Vitro SEM Study. $J$ Int Oral Health; 5(3): 14.

13. Oliveira ALBM, Garcia PPNS, Santos PA, Campos JADB. 2010. Surface Roughness and Hardness of a Composite Resin: Influence of Finishing and Polishing and Immersion Methods. Materials Research; 13(3): 410.

14. Wasilewski MA, Takahashi MK, Kirsten GA, de Souza EM. 2010. Effect of cigarette smoke and whiskey on the color stability of dental composites. American Journal of Dentistry; 23(1): 5.

15.Hamano N, Chiang YC, Nyamaa I, Yamaguchi H, Ino S, Hickel R, Kunzelmann KH. 2011. Effect of different surface treatments on the repair strength of a nanofilled resin-based composite. Dental Materials Journal; 30(4): 543.

16.Boyle P, Gray N, Henningfield J, Seffrin J, Zatonski W (ed.). 2004. Tobacco and Public Health: Science and Policy. Oxford: Oxford University Press, p. 53,62.

17. Anusavice KJ, Shen C, Rawls HR. 2013. Phillip's Science of Dental Materials. $12^{\text {th }}$ ed. St.Louis: Elsevier Saunders, p. 278-87.

18. Aisya RKN. 2008. Pengaruh Perendaman Obat Kumur Mengandung Eugenia Caryophyllata Oil Terhadap Kekerasan Resin
Komposit Tipe Hybrid. Jakarta: Universitas Indonesia, p. 8-9.

19.van Noort R. 2002. Introduction to Dental Materials. $2^{\text {nd }}$ ed. London: Mosby Elsevier, p.96-7, 109-13.

20.Maghfiroh H, Nugroho R, Probosari N. 2016. The effect of carbonated beverage to the discoloration of polished and unpolished nanohybrid composite resin. $J$ Dentomacillofac Sci; 1(1): 24.

21.Tirtosastro A, Murdiyati AS. 2010. Kandungan Kimia Tembakau dan Rokok. Buletin Tanaman Tembakau, Serat \& Minyak Industri; 2(1): 38-40.

22. Alandia-Roman CC, Cruvinel DR, Sousa ABS, Pires-de-Souza FCP, Panzeri H. 2013. Effect of cigarette smoke on color stability and surface roughness of dental composites. Journal of Dentistry; 4IS: e73-4.

23.Tantanuch $\mathrm{S}, \quad$ Kukiattrakoon $B$, Peerasukprasert T, Chanmanee N, Chaisomboonphun P, Rodklai A. 2016. Surface roughness and erosion of nanohybrid and nanofilled resin composites after immersion in red and white wine. J Conserv Dent; 19(1): 51-55.

24.Moraes RR, Goncalves LS, Lancellotti AC, Consani S, Correr-Sobrinho L, Sinhoreti MA. 2009. Nanohybrid Resin Composites: Nanofiller Loaded Materials or Traditional Microhybrid Resins. Operative Dentistry; 24(5): 553-4. 